\title{
RICE HUSK AS FILLER IN THE PRODUCTION OF BRICKS USING GBOKO CLAY
}

\author{
J. 0. Akinyele ${ }^{1, *}, 0$. T. Olateju ${ }^{2}$ and 0. K. Oikelome ${ }^{3}$ \\ 1,2,3 Department of Civil Engineering, Federal University of Agriculture, Abeokuta, OGUn State. Nigeria. \\ E-mail address:1joakin777@yahoo.com, ${ }^{2}$ bayolateju@yahoo.com,3 kennedy_oikelome@yahoo.com
}

\begin{abstract}
Rice Husk is a by-product of rice from agricultural processing which is usually disposed in landfill as waste. Farmers and rice millers normally burn the rice husk $(R H)$ as fuel in milling which leads to air pollution. This study looked at ways of converting the husk into materials for the construction industry. Chemical composition of RH and Gboko clay soil were investigated using $X$-ray diffraction test. Four grades $(75,150,300,425$ microns) of ground rice husk were mixed with clay at 0, 2, 4, 6, 8 and 10\%, by weight. The compressive strength and the lowest water absorption were determined. The chemical composition obtained for the $\mathrm{RH}$ showed that the total percentage compositions of $\mathrm{Fe}_{2} \mathrm{O}_{3}, \mathrm{SiO}_{2}$ and $\mathrm{Al}_{2} \mathrm{O}_{3}$ were found to be below $70 \%$ (class $\mathrm{C}$ ) which is the minimum requirement for pozzolans. The compressive strength test showed that test samples of $300 \mu \mathrm{m}$ gave the highest compressive strength of $5.47 \mathrm{~N} /$ $\mathrm{mm}^{2}$ at $2 \%$ admixture with the least water absorption of $0.379 \%$. Thus $2 \%$ of rice husk used as replacement for clay soil gave the best result. The study concluded that the use of Rice Husk as filler in production of bricks is suitable in the construction industry.
\end{abstract}

Keywords: Rice Husk, Gboko clay, Filler, Pozzolans, Compressive strength.

\section{INTRODUCTION}

The continuous increase in the cost of conventional items of building materials is becoming a serious problem, particularly for the people in developing countries who are finding it difficult to procure conventional building materials due to their low personal incomes. The cost of a unit block of sandcrete or plain concrete is relatively high. This calls for an urgent investigation in the manufacturing of bricks from these locally available materials. In recent times, a lot of investigations have been carried out in Nigeria on lateritic soils for the manufacturing of fired bricks. Laterite clays were also used to produce rope fiberreinforced earth blocks and plain fired bricks; the compressive strength of fiber reinforced earth blocks was improved by up to $50 \%$ over that of unreinforced block [1].The effect of palm fruit fibre in clay bricks was also investigated by Akinyele and Abdulraheem, [2], they observed that the fibre is a good moisture stabilizer in lateritic bricks, and the strength properties of the bricks were improved upon when $3 \%$ of palm fruit fibre was mixed with clay. The motive for the inclusion of waste materials in bricks making process has been to improve the strength. Various agricultural wastes such as Bagasse, Straw, and Groundnut Husk have been used to produce bricks. Falade [3] used Saw dust ash as partial replacement of cement in laterised bricks and found out that the addition of Saw dust ash decreases the compressive strength of the material. Rice husk ash was used to treat the compressibility characteristics of black cotton soil as fillings for embankment by Eberemu and Sada [4], the research concluded that the Rice Husk ash at $8 \%$ improves the compressive characteristics of the soil for its intended use. The use and disposal of rice husks has frequently proved difficult because of the tough, woody, abrasive nature of the husk, their low nutritive properties, and resistance to weather, great bulk and ash content. In fact in South East Asia, the accumulating heaps of rice husk have become significant problems, [5]. Other materials like ground nut shell [6],palm kernel shells [7], [8], also corn cob, periwinkle, coconut shell have been used as supplements or replacements for various civil engineering construction materials [9], [10]. Neem Seed Husk Ash (NSHA) which is a by-product 
obtained during the industrial processing of Neem seed to extract oil and produce fertilizer, was mixed with cement to determine it effect on concrete strength and workability [11], the research concluded that $5 \%$ mix of the material acts as a filler in concrete because of the high densities produced in it concrete. All these agricultural "waste" materials have been found to be reliable as partial replacement for either cement or aggregate in concrete and bricks.

Burnt clay bricks comprise of clay, sand and water only without any binder or additives. The poverty level amongst West African countries, particularly Nigeria, has made these blocks widely acceptable among the local populace so as to minimize the cost of construction. The improper use of these blocks has led to micro cracks on the walls after construction, [5]. The use of alternative cheaper local materials as stabilizer will greatly enhance the production of clay bricks with the desired properties at low cost. It will also drastically reduce the cost of production and consequently the cost of construction. Due to the increase in the cost of cement, it is becoming difficult as people can no longer afford to buy cement in large quantity for the construction of their houses. In Gboko town which is located in Benue State of Nigeria, most of the people there make use of Compressed Earth Bricks (CEB) and burnt bricks for the construction of their houses. The current cement production rate of the world is approximately 1.2 billion tons/year. This is expected to grow to about 3.5 billion tons/year by 2015, Nigerian Standard Organization [12]. The increase in demand for cement is expected to be met by partial cement replacement. The search for alternative binder or cement replacement materials led to the discovery of the potentials of using industrial by-products and agricultural wastes as building material. A survey by Raw Materials Research and Development Council of Nigeria on available local building materials reveals that certain building materials deserve serious consideration as substitute for imported ones. Few of these materials include: cement / lime stabilized bricks /blocks, sundried (Adobe) soil blocks, burnt clay bricks/ blocks, cast insitu walls, rice husk ash (RHA), straw and lime [12]. According to Nigeria Standard Organization [12] in their Annual report of 2004, over 5\% of global $\mathrm{CO}_{2}$ emissions can be attributed to Portland cement production. As the demand for cement continues to grow, the emissions caused by annual increases in production exceed gains, to reduce emissions through manufacturing efficiencies and cleaner fuels. Also the continuous increase in the cost of conventional building materials has prompted designers and developers to look for 'alternative materials' for the possible use in civil engineering constructions. The world rice harvest is estimated at 600 million tons per year, whereas in Niger State, Nigeria, about 96,660 tons of rice grains were produced in year 2000, [13].Rice husk constitutes about $20 \%$ of the weight of paddy rice, it contains about $50 \%$ cellulose, $25-35 \%$ lignin and $15-20 \%$ silica [4]. Thus the concrete and building industry offer an ideal method to integrate and utilize a number of these waste materials, which are socially acceptable, easily available, and economically within the buying powers of an ordinary man. The presence of such materials in cement concrete will not only reduce the carbon dioxide emission, but also impart significant improvement in workability and durability of concrete structures.

In the urban and rural areas of Nigeria, local milling is being done mostly by women, they mainly use firewood to thresh rice as heat source and as such one hundred percent of the rice husk from such mill are dumped in waste heap Figure 1. In developing countries like Nigeria, proper utilization of agricultural waste has not been given due attention. The rice husk thereby constitutes an environmental nuisance as it forms refuse heaps in the areas where it is disposed. The aim of this study is to examine the possibility of introducing rice husk as filler in the production of burnt bricks in Nigeria.

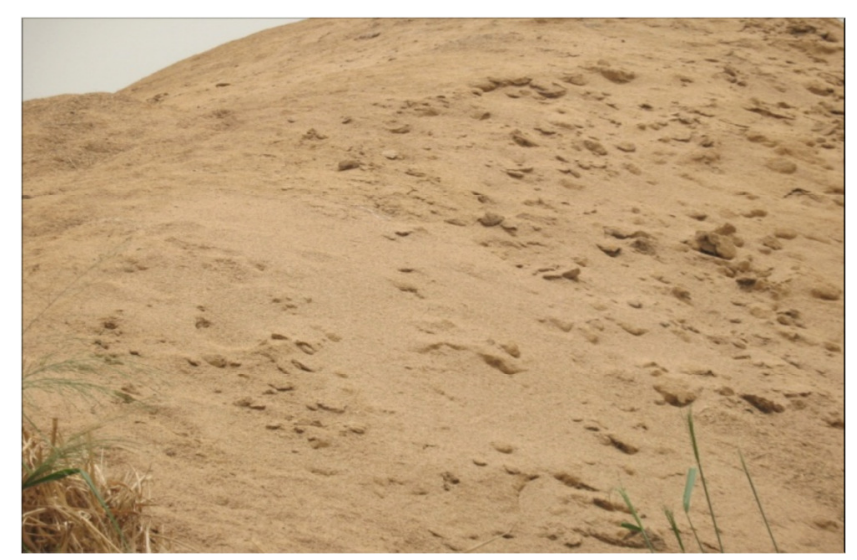

Figure 1: Deposited rice husk heap at a rice mill area

\section{METHODOLOGY}

\subsection{Sample Clay Soil}

Soil samples for this study were collected from the Bank of River Buruku at Gboko West Local Government Area of Benue State. A pit of $1 \mathrm{~m}$ depth was excavated with the aid of hoe, the particle size distribution of the clay samples were also carried out. 
All the experimental tests were carried out at the Dangote cement factory laboratory in Gboko, Benue Sate of Nigeria.

\subsection{Rice husk (Un-Burnt)}

The rice husk used for this study was collected from a local rice mill at Gwer East Local Government Area of Benue State. The Husk was stacked in heaps near the Mill. Samples were collected from different spots at the heap site. The samples were first air dried before taken to a grinding machine where they were ground in different grades:

Sample grade 1: Was not ground, Sample grade 2: was ground once, Sample grade 3: was ground twice: Sample grade 4: were ground into fine powder form and all the samples were then passed through sieves of different sizes (Table 1) where their particle size distribution were determined. The sieved husk was stored in air tight containers to avoid pre-hydration until usage. The rice husk was mixed in stepped increment of $0,2,4,6,8$ and $10 \%$ by weight to the clay soil.

Table 1: Different grinding process

\begin{tabular}{lllll}
\hline & $\begin{array}{l}\text { Once } \\
\text { ground }\end{array}$ & $\begin{array}{l}\text { Twice } \\
\text { ground }\end{array}$ & $\begin{array}{l}\text { Thrice } \\
\text { ground }\end{array}$ & $\begin{array}{l}\text { Ground } \\
\text { in } \\
\text { Powder } \\
\text { ed form }\end{array}$ \\
\hline $\begin{array}{l}\text { Sample } \\
\text { Grades }\end{array}$ & 1 & 2 & 3 & 4 \\
Sieve size & $425 \mu \mathrm{m}$ & $300 \mu \mathrm{m}$ & $150 \mu \mathrm{m}$ & $75 \mu \mathrm{m}$ \\
\hline
\end{tabular}

\subsection{Chemical composition of Rice Husk Using X- Ray Fluorescence Analysis}

A sample of $10 \mathrm{~g}$ was weighed using digital weighing equipment, the samples were placed into a metal disc with four number grind aid tablets, and this was to aid the grinding process. The disc was now taken into a machine where it was grind into a very fine powder, to confirm the fines, it was passed through 0 to $425 \mu \mathrm{m}$ digital sieve apparatus, the residue was now collected and converted into pellet by placing it into a steel ring of dimension $14 \mathrm{~mm} \times 40 \mathrm{~mm}$ wide after which it was subjected to an hydraulic machine with a pressure of $40 \mathrm{~N}$. The Rice husks were now converted to solid cylindrical mass which was finally taken into the Xray florescence machine for analyses. Inside the X-Ray Fluorescence (XRF) machine, there was an electronic rack, which was locked below the control panel, and dedicated microprocessor, which communicated with the main microprocessor control electronics. The sample transport mechanism integrated to accommodate a comprehensive range sample holder locked immediately to the right of the electronic rack. The sample transport mechanism was automatically transferred to the measuring position within the geometer and diffractometer housing, which returns automatically on completion of the analysis. The analysis was carried out under microprocessor control without the need for an operation. The analyses of the samples were displayed on the monitor of the desktop computer linked to it. The rice husk properties were determined by their diagnostic peaks and the mineralogical content of each representative sample were determined. The same process used in detecting the chemical composition of the rice husk was applied on the Gboko clay soil.

\subsection{Mixing of Rice Husk and Gboko Clay}

Each sample was weighed using a digital weighing machine, and the rice husk was mixed with the clay by weight at $0,2,4,6,8$ and $10 \%$, see Table2. The samples were now taken to a flat steel plate where the samples of the soil were broken into pieces and mixed with the rice husk,(The clay soil was partially replaced with the rice husk) the samples were now taken into a mixing machine and placed inside a steel pot like bowl, $200 \mathrm{ml}$ of water was measured and added to each of the samples, the machine was allowed to mix each sample for 3 minutes, (The $200 \mathrm{ml}$ of water was arrived at after carrying out some trial mix)then each admixture was then removed and placed inside a prism of $160 \times 40 \times 40 \mathrm{~mm}$ size, then the samples were now taken into jilting machine to compact the samples at 60 cycles per second for 2 minutes. The samples were then removed and kept at room temperature.

Table 2: Percentage Replacement of Clay with $R H$

\begin{tabular}{ccc}
\hline $\begin{array}{c}\text { Mix Proportion } \\
(\%)\end{array}$ & $\begin{array}{c}\text { Mass of Clay } \\
(\mathrm{g})\end{array}$ & $\begin{array}{c}\text { Mass of Rice } \\
(\mathrm{g})\end{array}$ \\
\hline 0 & 1000 & 0 \\
2 & 980 & 20 \\
4 & 960 & 40 \\
6 & 940 & 60 \\
8 & 920 & 80 \\
10 & 900 & 100 \\
\hline
\end{tabular}

\subsection{Wetting, Drying and Compressive Strength test}

Three bricks were molded from each admixture. After careful drying at room temperature $\left(29^{\circ} \mathrm{C} \pm 2^{\circ} \mathrm{C}\right)$ for 24 hours, the bricks were then fired in an electric 
muffle furnace with a rise of $200^{\circ} \mathrm{C} / \mathrm{h}$ and $800^{\circ} \mathrm{C}$ for 4 hours. The compressive strength of each brick was determined in accordance with the Specification of the Standard Organization of Nigeria (SON) as contained in Test for Compressive Strength of Solid Bricks [12].The corresponding strength was recorded using a concrete compressive testing machine.

Three bricks were preconditioned by immersion in water at room temperature $\left(29^{\circ} \mathrm{C} \pm 2^{\circ} \mathrm{C}\right)$ for 24 hours, they were then removed and all traces of water wiped off, and then stored under moist conditions for 24 hours prior to testing. The bricks were centrally positioned between the platens of the testing machine, and then the load was gradually increased until failure.

In order to determine the water absorption property of the bricks, a set of three bricks were preconditioned by drying in an oven at $100^{\circ} \mathrm{C}$ for 5 minutes until they attained constant mass and then cooled to room temperature and weighed to note their initial weight $M_{1}$. These bricks were later immersed in cold water at room temperature $\left(29^{\circ} \mathrm{C} \pm 2\right)$ for 24 hours and thereafter removed and every trace of water was wiped off. The bricks were then weighed to note their increased weight $\mathrm{M}_{2}$. The water absorption defined as the relative increase in weight, which was thus calculated. Figure 2 showed some samples of the burnt bricks, these processes were repeated for all the percentage mix of rice husk and clay.

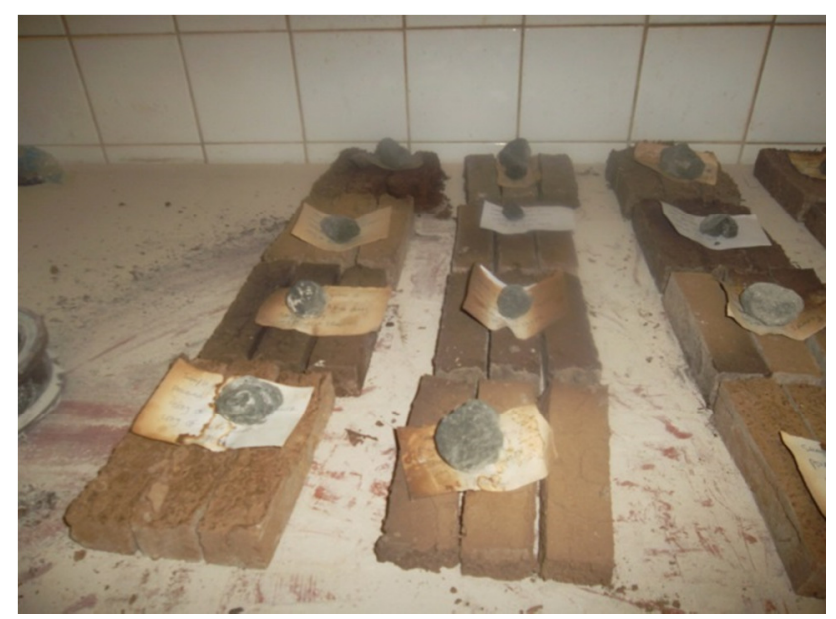

Figure 2: Samples of burnt bricks

\section{RESULTS}

\subsection{Chemical Composition of Rice Husk and Clay}

The chemical composition of un-burnt rice husk after $\mathrm{X}$-Ray Fluorescence analysis is shown in Table 3. The $\mathrm{X}$-Ray Fluorescence Machine was able to detect the element after the rice husk was ground in to a very fine powder which was converted into pellet. The pellet were inserted into the $\mathrm{X}$-Ray Machine and revealed major Oxides as $\mathrm{Si}_{2}, \mathrm{Al}_{2} \mathrm{O}_{3}, \mathrm{Fe}_{2} \mathrm{O}_{3}$ and $\mathrm{CaO}$, while the minoroxides were, $\mathrm{MgO}, \mathrm{Na}_{2} \mathrm{O}, \mathrm{K}_{2} \mathrm{O}$ and $\mathrm{SO}_{3}$. The total composition of Iron Oxide $\left(\mathrm{Fe}_{2} \mathrm{O}_{3}\right)$, Silicon Dioxide $\left(\mathrm{SiO}_{2}\right)$ and Aluminium Oxide $\left(\mathrm{Al}_{2} \mathrm{O}_{3}\right)$ was found to be $56.7 \%$. This was less than the $70 \%$ as minimum specification of (ASTM C618-84) for Pazollans, [14] thus it is a class " $\mathrm{C}$ " pozzolan, and satisfied the objective of the study in the use of un-burnt Rice Husk as inert filler in the fired brick.

Table 3 also shows the geochemical composition of Gboko Clay Soil while Figure 3 showed the particle size distribution of the clay. The particle size distribution showed that majority of the particles falls between 0.075 to $1.70 \mathrm{~mm}$ particle size, which is the BS 1377 part 2 [16] recommendation for sand and medium clay. The chemical composition of the soil showed that it contains over $70 \%$ of $\mathrm{Si}_{2}, \mathrm{Al}_{2} \mathrm{O}_{3}$, andFe $\mathrm{O}_{3} \mathrm{O}_{3}$ which qualifies it as a class " $\mathrm{F}$ " pozzolan, this means that it is a good pozzolan.

\section{Table 3: Rice Husk and Gboko Clay Chemical composition}

\begin{tabular}{lllll}
\hline $\mathrm{s} / \mathrm{n}$ & Element & $\begin{array}{l}\text { Chemical } \\
\text { composition of } \\
\text { Rice Husk }\end{array}$ & $\begin{array}{l}\text { Chemical } \\
\text { composition of } \\
\text { Gboko Clay soil }\end{array}$ & Unit \\
\hline 1 & $\mathrm{Si}_{2}$ & 43.37 & 29.11 & $\%$ \\
2 & $\mathrm{AL}_{2} 0_{3}$ & 10.65 & 31.44 & $\%$ \\
3 & $\mathrm{Fe}_{2} 0_{3}$ & 2.68 & 12.56 & $\%$ \\
4 & $\mathrm{Ca} 0$ & 1.74 & 7.55 & $\%$ \\
5 & $\mathrm{Mg} 0$ & 0.41 & 3.96 & $\%$ \\
6 & $\mathrm{Na}_{2} 0$ & 0.04 & 0.16 & $\%$ \\
7 & $\mathrm{~K}_{2} 0$ & 0.51 & 0.08 & $\%$ \\
8 & $\mathrm{SO}_{3}$ & 0.26 & - & $\%$ \\
9 & L.O.I & & & \\
\hline
\end{tabular}

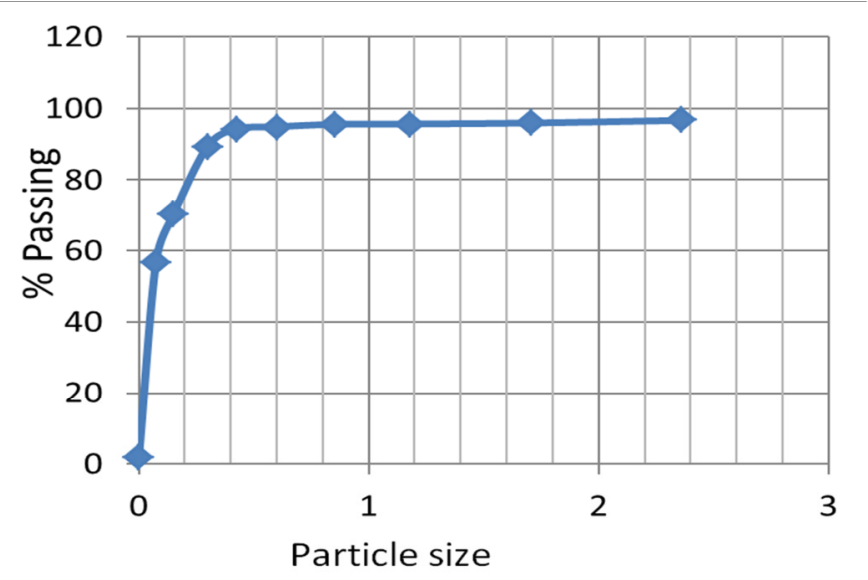

Figure 3: particle size distribution of soil sample

\subsection{Compressive strength test results.}

Table 4 serves as the control of the compressive strength for burnt Gboko clay soil without treatment 


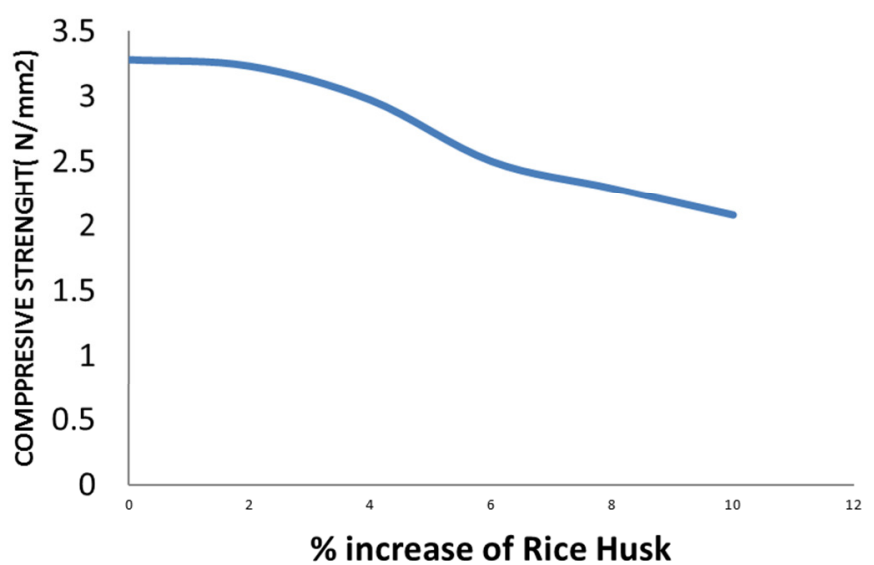

Figure 4: Compressive strength result for grade1 RH

of rice husk and showed an average strength of 3.28 $\mathrm{N} / \mathrm{mm}^{2}$ at 28 days with a water absorption level of $0.71 \%$. Bricks are classified by both the average or minimum compressive strength and the percentage water absorption. According to the classification, minimum compressive strength of bricks should be $3.5 \mathrm{~N} / \mathrm{mm}^{2}$ and the water absorption should not exceed 20\%. [15].

Table 4: Compressive Strength test Result for Untreated Gboko Clay

\begin{tabular}{lllll}
\hline & B1 & B2 & B3 & Average \\
\hline $\begin{array}{l}\text { Sample weight } \\
\text { after burning } \\
(\mathrm{g})\end{array}$ & 283.00 & 282.00 & 280.00 & - \\
$\begin{array}{l}\text { Sample Area } \\
\left(\mathrm{mm}^{2}\right)\end{array}$ & 6.40 & 6.40 & 6.40 & - \\
$\begin{array}{l}\text { Crushing Load } \\
(\mathrm{kN})\end{array}$ & 20.87 & 20.71 & 20.38 & 20.99 \\
$\begin{array}{l}\text { Compressive } \\
\text { Strength(N/mm }\end{array}$ & 3.26 & 3.24 & 3.34 & 3.28 \\
$\begin{array}{l}\text { 2) } \\
\text { Water }\end{array}$ & 0.701 & 0.704 & 0.709 & 0.71 \\
\hline Absorption (\%) & & & & \\
\hline
\end{tabular}

\subsubsection{Grade1 samples (425 $\mu \mathrm{m}$ )}

Grade 1 which was the uncrushed rice husk was mixed with clay at $2 \%$, and at 28 days, the compressive strength was $3.23 \mathrm{~N} / \mathrm{mm}^{2}$ with water absorption of $0.60 \%$, the $4 \%$ of rice husk mix, gave the compressive strength of $2.97 \mathrm{~N} / \mathrm{mm}^{2}$ with water absorption of $0.95 \%$.The compressive strength for $6 \%$ rice husk showed $2.50 \mathrm{~N} / \mathrm{mm}^{2}$ with water absorption of $1.05 \%$. For the $8 \%$ of rice husk the compressive was 2.29 $\mathrm{N} / \mathrm{mm}^{2}$ with water absorption of $1.06 \%$.The last compressive strength for grade 1 of the mix design showed that with a mix of $90 \%$ of clay and $10 \%$ of rice husk the compressive strength was $2.08 \mathrm{~N} / \mathrm{mm}^{2}$ with

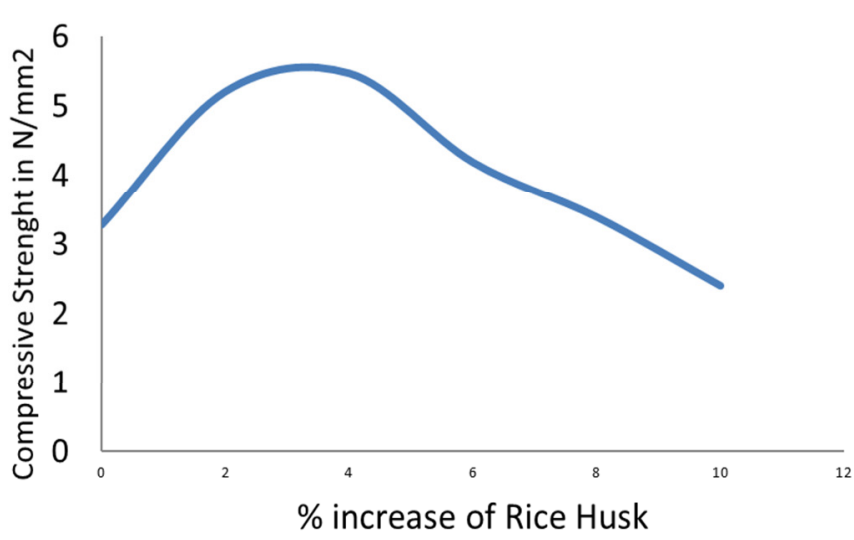

Figure 5: Compressive strength result for grade2 $\mathrm{RH}$.

water absorption of $1.33 \%$.The graph of compressive strength of Rice Husk for grade samples 1 shows that with an increase in the percentage of rice husk, there was a reduction in the compressive strength figure 4.

\subsubsection{Grade 2 samples $(300 \mu \mathrm{m})$}

The grade 2 samples was mix with $98 \%$ of clay, and gave the compressive strength of $5.47 \mathrm{~N} / \mathrm{mm}^{2}$ with water absorption of $0.379 \%$, for the $96 \%$ mix of clay gave compressive strength of $5.21 \mathrm{~N} / \mathrm{mm}^{2}$ with water absorption of $0.38 \%$. The compressive strength for $94 \%$ clay mix gave $4.19 \mathrm{~N} / \mathrm{mm}^{2}$ with water absorption of $0.51 \%$. For $92 \&$ of clay has compressive of $3.39 \mathrm{~N} / \mathrm{mm}^{2}$ with water absorption of $0.61 \%$.The last compressive strength for grade 2 of the mix design shows that with a mix of $90 \%$ of clay compressive strength is $2.40 \mathrm{~N} / \mathrm{mm}^{2}$ with water absorption of 0.695 $\%$. Figure 5 shows the graph of compressive strength of rice husk for grade samples 2, with an increase in the percentage of rice husk, there was a reduction in the compressive strength.

\subsubsection{Grade 3 sample $(150 \mu m)$}

The $2 \%$ mix design of rice husk and clay, gave compressive strength of $4.11 \mathrm{~N} / \mathrm{mm}^{2}$ with water absorption of $0.54 \%$, at $4 \%$ of rice husk in clay, the compressive strength is $3.85 \mathrm{~N} / \mathrm{mm}^{2}$ with water absorption of $0.51 \%$.The compressive strength for $6 \%$ of rice husk in clay shows $3.49 \mathrm{~N} / \mathrm{mm}^{2}$ with water absorption of $0.49 \%$. For $8 \%$ of rice husk in clay the compressive is $3.32 \mathrm{~N} / \mathrm{mm}^{2}$ with water absorption of $0.46 \%$.The last compressive strength for $10 \% \mathrm{mix}$ was $3.07 \mathrm{~N} / \mathrm{mm}^{2}$ with water absorption of $0.44 \%$. Figure 6shows the graph of compressive strength. 


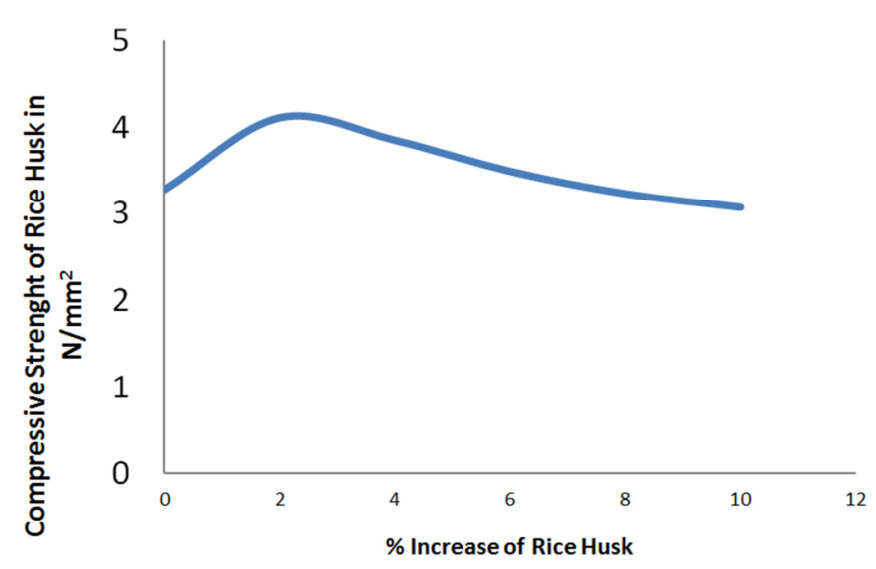

Figure 6: Compressive strength for grade 3 samples.

\subsubsection{Grade 4 samples (75 $\mu \mathrm{m})$}

The mix design of $2 \%$ addition of the admixture of rice husk, at 28 days, gave the compressive strength of $3.70 \mathrm{~N} / \mathrm{mm}^{2}$ with water absorption of $0.48 \%$, at $4 \%$ admixture; the compressive strength was $3.18 \mathrm{~N} / \mathrm{mm}^{2}$ with water absorption of $0.45 \%$.The compressive strength for $6 \%$ of rice husk shows 3.10 $\mathrm{N} / \mathrm{mm}^{2}$ with water absorption of $0.43 \%$. For the $8 \%$ of rice husk, the compressive strength was $3.05 \mathrm{~N} / \mathrm{mm}^{2}$ with water absorption of $0.41 \%$.The $10 \%$ of rice husk gave a compressive strength of $3.01 \mathrm{~N} / \mathrm{mm}^{2}$ with water absorption of $0.40 \%$. Figure 7 shows the graph of compressive strength.

\section{DISCUSSION}

Generally, the overall result has shown that with the increase of Rice Husk to the clay soil there is a decrease in the strength. The specific gravity of the Rice Husk was found to be 2.13 while that of untreated clay was found to be 2.37. The water absorption characteristics of the bricks showed that minimum water absorption of $0.38 \%$ was obtained for bricks made with $4 \%$ Rice Husk compared to $0.71 \%$ water absorption for plain brick, the maximum value of $1.33 \%$ was obtained for bricks made with $10 \%$ rice husk which was less than $20 \%$ prescribed in the standard. The increase in compressive strength of the bricks from $3.28 \mathrm{~N} / \mathrm{mm}^{2}$ for Clay not treated with Rice Husk at $0 \%$ to $5.47 \mathrm{~N} / \mathrm{mm}^{2}$ at $2 \%$ Rice Husk might have been caused by the presence of $\mathrm{CaO}$ (Calcium oxide) in Rice Husk in very small quantity which reacted with the soil to form silicate of calcium at the introduction of water. These results is similar to the one obtained by Akinyele and Abdulraheem [2], Where the compressive strength of fibre reinforced compressed clay bricks increased at 3\% mix but diminished in strength at higher mix. The $2 \%$ mix of

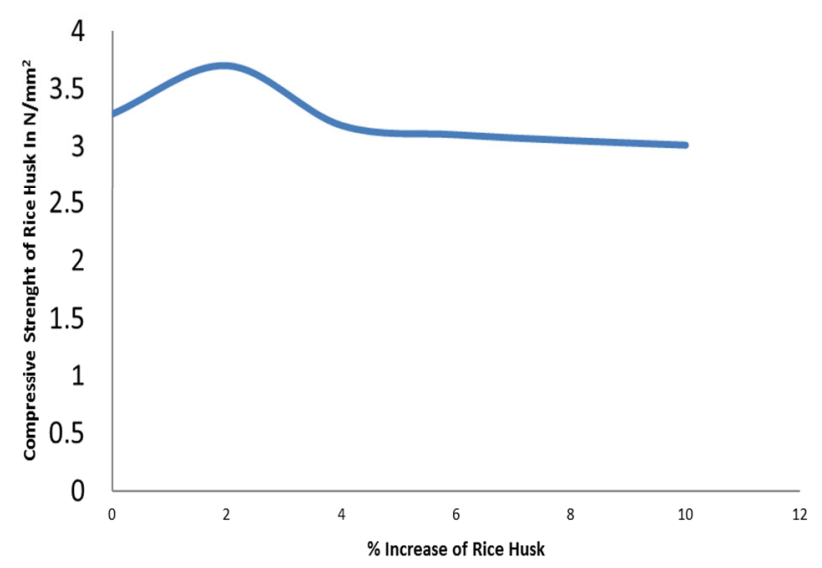

Figure 7: Compressive strength test results for grade 4.

grade 2 gave the highest compressive strength when compared to the other grades although the other grades also gave a higher strength at $2 \%$ when compared to the control, this is because the size of the crushed rice husk in these grades falls within the same range as the particle size of the clay used. The particles of the rice husk in the mixture enhance the binding ability of the bricks material at this percentage, the rice husk particle were able to absorb the water in the mix, hence the rapid setting time and high strength obtained in the bricks. Okafor and Okonkwo [17] Asserted that rice husk has high affinity for water, and this must have led to this action. The excess of the rice husk in the clay increased the amount of water absorbed by the bricks and this excess water weakened the inter-particles bonding that could have been formed by the soil and rice particles, hence the reduction in compressive strength as the percentage of rice husk increases. This was probably responsible for the increased water absorption obtained during the water absorption test, or it might be explained that during verification at $800^{\circ} \mathrm{C}$, that the melting temperature of rice husk and that of the clay differed thereby resulting to a heterogeneous compound whose strength diminished with increase Rice Husk and water absorption increased with increase in Rice Husk. The ungrounded grade has the lowest strength because of the fluffy nature of the rice husk. The grinding of the rice husk into smaller particles also contributed to the high compressive strength obtained in the results, this is because the grounded particles provided a smaller surface for proper bonding and blending with the small clay particles and this encourages an interparticle attractive forces. The clay particle has water repelling characteristics whereas the rice husk has affinity for water, this property allows for physico- 
chemical reaction which will bring about the exchange of cations between the two materials. The broken surface of the rice husk as a result of grinding allows it to absorb water easily and this encourages the hydration process of the clay particle.

\section{CONCLUSION}

The investigation has showed that the rice husk can serve as an inert filler to increase the intermolecular bonding and increase in compressive strength within the Gboko clay soil at $4 \%$ rice husk in clay.

It is therefore recommended that $4 \% \mathrm{RH}$ admixtures for samples grade 2, 3 and $4(300 \mu \mathrm{m}, 150 \mu \mathrm{m}$ and 75 $\mu \mathrm{m})$ can be used to enhance the properties of Gboko clay, because the compressive strength results are higher than the $3.5 \mathrm{~N} / \mathrm{mm}^{2}$ values recommended by standard, the water absorption was lower than the $20 \%$ maximum recommendation, which is also good, but the compressive strength characteristics above $4 \%$ mixture are very poor, Hence, Gboko clay can be used for brick production with addition of $\mathrm{RH}$ below $4 \%$.

\section{REFERENCES}

[1] Rowe, R. K., Quigley, R. M. and Booker, J. R. (1995). "Clayey Barrier System for waste Disposal Facilities". E\&FN Spon. An Imprint of Chapman \& Hall. 2-6 Boundary Row London. pp. 1-360.

[2].Akinyele, J.O, and Abdulraheem, W. (2014). "Effect of Palm Fruit on the Compressive Strength of Lateritic Bricks at Different Curing Ages". Proceedings of the AES- ATEMA 18 $18^{\text {th }}$ international conference, 2014, Toronto Canada.

[3] Falade S. (1990). "Effect of saw dust ash on the strength of laterised concrete" West Indies Journal of Engineering Vol. (1), Pp 71-85.

[4] Eberemu, A. 0 and Sada, H. (2013). "Compressibility Characteristics of Compacted Black Cotton soil Treated with Rice Husk Ash" Nigerian Journal of Technology. Vol. 33 (3), pp 507-521.

[5] Oakley, R. E. (1987). "Design and Performance of Earth-Lined Containing Systems" Geotechnical Practice for waste Disposal 87, R.D. Woods, ed.,

[6] Sada, B. H, Amartey, Y. D and Bako, S. (2013). "Investigation into the use of groundnut shell as fine aggregate replacement" Nigerian Journal of Technology Vol. 32. 1. pp 54-60.

[7]. Otunyo, A. W, Nuaka, B. Faith, J.C. (2011). “ Combination of palm Kernel Husk Ash (PKHA) and Free lime ( $\mathrm{CaO})$ as an Admixture in Concrete Production" Nigerian Journal of Technology, Vol.30 (1), pp 64-71.

[8]. Otunyo, A. W. (2011). "Palm kernel Husk Ash as an admixture (Accelerator) in Concrete. Nigerian Journal of Technology (NIJOTECH), Vol.30 (3), pp 60-66.

[9] Olanipekun, E. A, Olusola, K. O and Ata. O. (2006). "A comparative study of Concrete Properties Using coconut shell and palm kernel shell as coarse aggregate" Building and Environment, Vol. 41 (3), pp 297-301.

[10] Adesanya, D. A and Raheem, A. A. (2009). " A study of the workability and compressive strength Characteristics of Corn cob ash blended cement concrete" Construction and Building Materials. Vol. 23 (1). Pp 311-317

[11] Ejeh, S. P, Abubakar, I, Ocholi, A and Nurudeen, M. M. (2014). " Effect of Neem Seed Husk Ash on Concrete Strength Properties" Nigerian Journal of Technology Vol.33 (2), pp 163-169.

[12] Nigerian Standard Organization (2010). Specification for burnt clay building units. Nigeria Industrial Standard 74, UDC 6240128 . Federal Ministry of Industries, Lagos, Nigeria.

[13] Edodzigi, M., (2001) "Cropped Area and Yield Survey (CAYS) report 2000 wet season". Agricultural Development Project (ADP), Niger State, Nigeria Pg 2.

[14] American Standard for Testing Materials, (ASTM C 618- 84). "Specifications for Portland Pozzolans".

[15]. Brick Development Association, (1974) "Bricks, their properties and use." Construction press Limited.

[16] British Standard Institution BS 1377 (1990). “ Methods of testing for Soils for Civil Engineering purpose"

[17] Okafor, F. O and Okonkwo, N. (2009). " Effect of Rice Husk Ash on some Geotechnical Properties of Lateritic Soil" Nigerian Journal of Technology, Vol.28 (1), pp 46-52. 